\title{
EXTENSION OF SERVICE LIFE OF WELDED TANKS OF STAINLESS STEEL BY INCREASING PITTING RESISTANCE
}

\author{
V.M. KULIK, S.A. OSADCHUK, L.I. NYRKOVA, V.P. ELAGIN and S.L. MELNICHUK \\ E.O. Paton Electric Welding Institute, NASU \\ 11 Kazimir Malevich Str., 03680, Kiev, Ukraine. E-mail: office@paton.kiev.ua
}

\begin{abstract}
During long service of the tanks, manufactured of stainless steel, the pits are formed on the surface contacting with periodically preheated aggressive liquid, mainly in welded joints, and the danger of through fracture of wall arises. The aim of the work was to increase the reliability and longevity of tanks for storage of aggressive liquid, first of all, by increasing the resistance of welded joints against pitting formation. The specimens, being untreated and mechanically treated in different ways with penetration of the untreated surface and polished sheet steel $12 \mathrm{Kh} 18 \mathrm{~N} 10 \mathrm{~T}$ were subjected to accelerated tests for resistance against pitting corrosion at room temperature and preheatings of $\mathrm{FeCl}_{3}$ solution similar to the technological ones. The resistance against pitting corrosion of welded joints is significantly increased after abrasive treatments, surface peening to a lesser extent and is independent of the surface roughness. The pitting resistance is also increased by replacing the indirect preheating of solution through the specimen to its direct preheating by the immersed heater. The results of the work are advisable for using in manufacture, repair and service of chemical, petrochemical, food and other equipment. 9 Ref., 2 Tables, 5 Figures.
\end{abstract}

K eyw ord s: tank, stainless steel, welded joint, pitting corrosion, abrasive treatment, peening, preheating, surface roughness

In the production of abrasives the formalin is used supplied from vertical welded tank of $3.2 \mathrm{~m}$ diameter and $7.2 \mathrm{~m}$ height manufactured of corrosion-resistant two-layer steel $12 \mathrm{Kh} 18 \mathrm{~N} 10 \mathrm{~T}$. In the process of long service of the tank, formalin preheated for technological purposes, mainly in cold season, causes the formation and development of corrosion pits on clad layer, mostly in welded joints and bottom. When the pits reach the base layer, the corrosion process is intensified resulting in through corrosion fracture of the wall in short time and environmental pollution with combustible toxic substances. At the E.O. Paton Electric Welding Institute the monitoring procedure was developed [1], which allows establishing the moment of violation of clad sealing by the pitting. For rewelding the local corrosion fractures a long break in tank service is required, which leads to material and labor expenses.

The aim of the work is the increase of service reliability and longevity of tanks for storage of aggressive liquids by increasing their resistance, first of all welded joints of stainless steel, against pitting formation.

The analysis of pits distribution in the tank evidences of a noticeable influence of temperature, method of formalin preheating, spatial position and duration of wall contact with formalin, thermal effects on metal during welding and the possible influence of surface metal condition on their formation. A partial confirmation to this fact is a higher tendency of stainless steel to pitting corrosion established by us at its horizontal arrangement unlike the vertical one, that was taken into account during corrosion tests.

It is known that corrosion-resistant steels are prone to pitting corrosion [2] due to the formation of galvanic couple between the passivated surface and its separate areas unpassivated for different reasons. The development of pits inside depth occurs at rate exceeding the rate of uniform corrosion by ten thousand times.

The tendency of stainless steel to pitting corrosion increases usually with increase in temperature of aggressive solution and depends on the type and temperature of heat treatment and the subsequent heating $[3,4]$. The resistance to pitting corrosion of austenitic steel $12 \mathrm{Kh} 18 \mathrm{~N} 10 \mathrm{~T}$ increases by tensile deformation with the formation of martensitic $\alpha^{\prime}$-phase [5]. The increase in resistance against stress corrosion and corrosion fatigue failure are positively affected by rollers running, shot blasting, scratching by metallic brush, reduction of roughness of stainless steel surface and its welded joints, as well as high-frequency machining treatment of welded joints of low-alloyed steels [6-8].

To clarify the influence of state of the metal and surface of welded joint of stainless steel as well as the method of preheating the aggressive solution contacting with it on pitting formation, the plane specimens of $50 \times 70 \mathrm{~mm}$ sheet steel $12 \mathrm{Kh} 18 \mathrm{~N} 10 \mathrm{~T}$ of $8 \mathrm{~mm}$ thickness in as-delivered state, and $7 \mathrm{~mm}$ thickness 


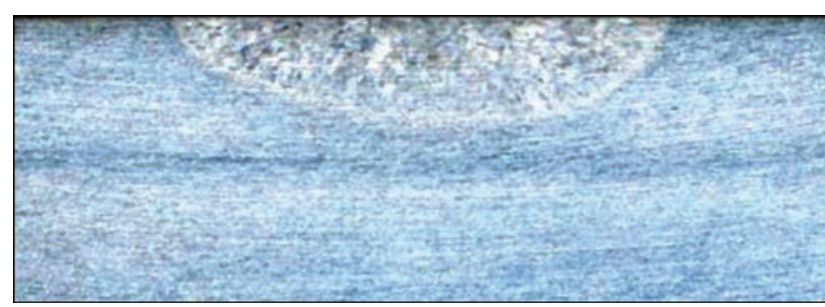

Figure 1. Penetration of high-alloyed steel of $8 \mathrm{~mm}$ thickness using tungsten electrode in argon

after finishing grinding with emulsion cooling were manufactured to remove the possible surface defects.

The specimens were subjected to partial penetration using tungsten-electrode argon-arc welding without filler metal (TIG) applying welding machine ARK-1 with power source VDUCh-315. Observing $I_{\mathrm{w}}=150 \mathrm{~A}, U_{\mathrm{a}}=11 \mathrm{~V}$ and $v_{\mathrm{w}}=5.5 \mathrm{~m} / \mathrm{h}$, the depth, width and reinforcement (excess of base metal surface) of penetration amounted to 3,11-13 and about $0.5 \mathrm{~mm}$, respectively (Figure 1), that is acceptable for rewelding the local fractures of inner surface of the tank. The weld metal (of penetration) is produced almost with the same chemical composition as the base metal, and the columnar crystallites of the upper part of weld are oriented generally normally to the surface.

A part of the specimens of welded joints was subjected to the following surface machining: using abrasive disc on grinding machine-tool also with the subsequent manual abrasive treatment using skin with the formation of clearly visible scratches, using vulcanite disc on grinding machine-tool until getting a mirror shine (polishing), using edge friction with and without elastic shocks by hardened steel rod using a hand drill with the formation of poorly-visible scratches, using manual and high-frequency mechanical peening with the formation of dents.

The untreated weld is characterized by rippled surface in the form of isotherms of weld pool solidification. They are eliminated by abrasive treatments, friction with the formation of plurality of scratches of different depth, frequency of distribution and peening with surface plastic deformation of metal without

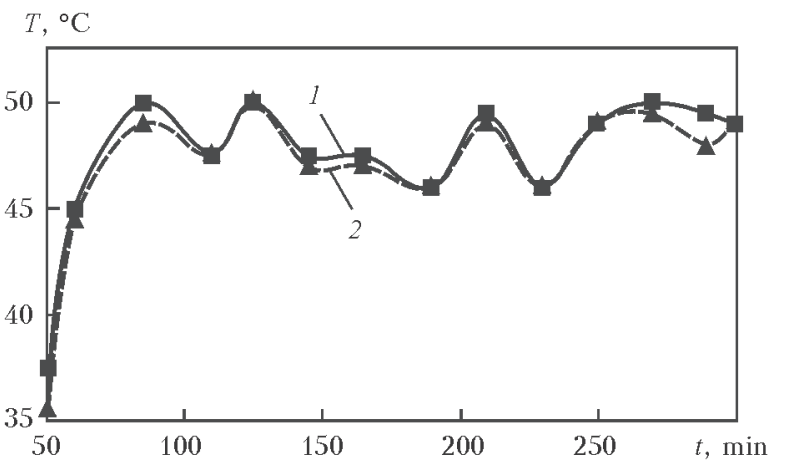

Figure 2. Change of temperature of water $\mathrm{FeCl}_{3}$ solution heated on electric plate at distance of 5 (1) and 45 (2) $\mathrm{mm}$ from the surface of specimen the formation of scratches. After these treatments the weld surface is determined only by its reinforcement above the base metal.

The corrosion tests for revealing the tendency to pitting corrosion of horizontally arranged welded specimens were carried out in $10 \%$ water solution of $\mathrm{FeCl}_{3}$ at room temperature of $25-27{ }^{\circ} \mathrm{C}$ during 5, 24, 48 and $72 \mathrm{~h}$ in the process of preheating during $5 \mathrm{~h}$ according to GOST 9.912-89. The preheating of the solution column of $90 \mathrm{~mm}$ height in cylindrical cell of $40 \mathrm{~mm}$ diameter, installed vertically on the specimen surface, was carried out on electric plate through the specimen and using the electric heater immersed into the solution to depth of $45 \mathrm{~mm}$ during cooling the specimen by running tap water of $18-20^{\circ} \mathrm{C}$ from the reverse side. The temperature of the solution at different levels was controlled by the submerged mercury thermometer and regulated by operation changes of the supplied voltage of the laboratory autotransformer and also by forced cooling of test tube with cold water submerged from the top.

In the process of preheating the water solution on electric plate the temperature rises to $45^{\circ} \mathrm{C}$ during $1 \mathrm{~h}$ and is stabilized at $46-50{ }^{\circ} \mathrm{C}$ after expiration of $75-$ $80 \mathrm{~min}$ (Figure 2). At the same, time due to convection a small difference of temperatures of the solution of $0-1.5{ }^{\circ} \mathrm{C}$ is established in the range of $5-45 \mathrm{~mm}$ from the specimen. Under the conditions of convective heat exchange the temperature of the specimen surface is slightly higher than the temperature of preheating solution.

During preheating using the immersed electric heater the temperature of solution near the surface of the specimen increases longer and to the lower values than it does near the heater, and is stabilized at 28.0-28.5 and $51-56{ }^{\circ} \mathrm{C}$ at distance of 5 and $45 \mathrm{~mm}$ from the surface of specimen after $110 \mathrm{~min}$ of preheating (Table 1). Taking into account the gradient of temperatures along height of $0.55-0.60{ }^{\circ} \mathrm{C} / \mathrm{mm}$, the temperature of solution at the very surface of specimen should be $25-26{ }^{\circ} \mathrm{C}$. The absence of convection causes decreased intensity of heat exchange and preheating of the specimen, that in combination with its

Table 1. Change of temperature of $\mathrm{FeCl}_{3}$ water solution in height preheated by immersed heater and cooled beneath

\begin{tabular}{|c|c|c|c|c|c|}
\hline Preheating & \multicolumn{5}{|c|}{ Temperature of solution $\left({ }^{\circ} \mathrm{C}\right)$ in height $(\mathrm{mm})$} \\
\cline { 2 - 6 } duration, min & 5 & 15 & 25 & 33 & 45 \\
\hline 0 & 22 & 22 & 24 & 24 & 24 \\
$50-58$ & 25 & 29 & 31 & 41 & 52 \\
$75-80$ & 27 & 31 & - & 44 & 52 \\
$110-120$ & 28 & 34 & 40 & 48 & 51 \\
$163-171$ & 28.5 & - & 41 & - & 56 \\
$197-240$ & 28.5 & 34 & - & 48 & 53 \\
\hline
\end{tabular}




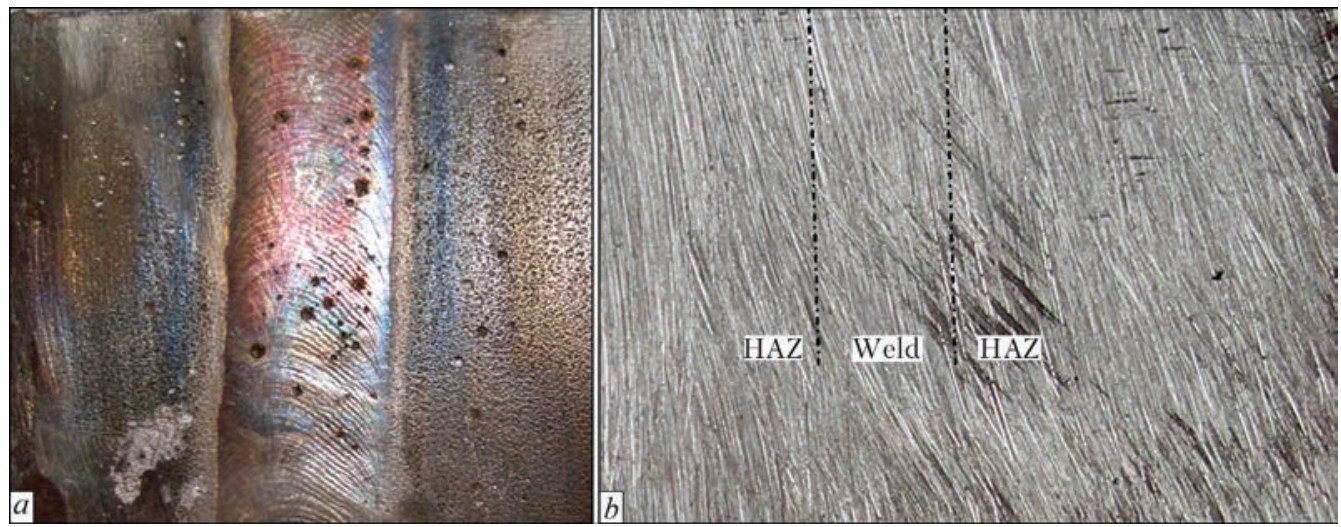

Figure 3. Surface of welded joint of sheet steel 12Kh18N10T tested for pitting corrosion during $5 \mathrm{~h}$ in as-welded state $(a)$ and after abrasive treatment $(b)$

forced cooling from the reverse side (as a wall of the tank in the cold season) determines the establishment of temperature on its surface being lower than it does during preheating on electric plate, being at least 20 $25^{\circ} \mathrm{C}$ and lower than room temperature.

Under the influence of $\mathrm{FeCl}_{3}$ solution at room temperature the untreated welded joint of stainless steel in as-delivery state is prone to pitting formation: the relatively large ones on the weld and smaller different ones at distance of 3-8 $\mathrm{mm}$ from the weld and more (Figure 3, $a$; Table 2).

A high tendency to pitting formation of the joint can be explained by the appearance of tensile stresses in the surface layer [7], enrichment of border areas of the columnar crystallite cells near the surface of weld metal with sulfur and other impurities, and the

Table 2. Pitting formation in welded joints of steel 12Kh18N10T depending on treatment

\begin{tabular}{|c|c|c|c|c|c|}
\hline \multicolumn{3}{|c|}{ Treatment method. Roughness of surface $R a, \mu \mathrm{M}$} & \multirow{3}{*}{ Test duration, $\mathrm{h}$} & \multicolumn{2}{|c|}{ Number of pits, pcs* } \\
\hline \multirow{2}{*}{ Steel } & \multicolumn{2}{|c|}{ Joint } & & Penetration & $\mathrm{HAZ}$ \\
\hline & Weld & HAZ & & Pentil ationi & $11 \pi 2$ \\
\hline \multirow{2}{*}{$\begin{array}{l}\text { Without treatment. } \\
0.2-1.6\end{array}$} & \multicolumn{2}{|c|}{ Without treatment } & \multirow{2}{*}{5} & \multirow{2}{*}{26} & \multirow{2}{*}{60} \\
\hline & After welding & $0.2-1.6$ & & & \\
\hline \multirow{2}{*}{ Same } & \multicolumn{2}{|c|}{ Using abrasive disc } & \multirow{2}{*}{5} & \multirow{2}{*}{2} & \multirow{2}{*}{5} \\
\hline & $40-60$ & $40-60$ & & & \\
\hline \multirow[b]{2}{*}{$»$} & \multicolumn{2}{|c|}{ Using abrasive disc and skin } & \multirow{2}{*}{5} & \multirow{2}{*}{1} & \multirow{2}{*}{2} \\
\hline & $20-40$ & $20-40$ & & & \\
\hline \multirow{4}{*}{ Grinding. $0.2-0.8$} & \multirow{2}{*}{\multicolumn{2}{|c|}{ Without treatment }} & 5 & 20 & 1 \\
\hline & & & 24 & 20 & 1 \\
\hline & \multirow{2}{*}{ After welding } & \multirow{2}{*}{$0.2-0.8$} & 48 & 20 & 1 \\
\hline & & & 72 & 20 & 1 \\
\hline \multirow{4}{*}{ Same } & \multirow{2}{*}{\multicolumn{2}{|c|}{ Manual peening }} & 5 & 14 & 1 \\
\hline & & & 24 & 14 & 1 \\
\hline & \multirow{2}{*}{\multicolumn{2}{|c|}{ After peening }} & 48 & 14 & 1 \\
\hline & & & 72 & 14 & 1 \\
\hline \multirow{4}{*}{$»$} & \multirow{2}{*}{\multicolumn{2}{|c|}{ High-frequency mechanical peening }} & 5 & 14 & 1 \\
\hline & & & 24 & 14 & 1 \\
\hline & \multirow{2}{*}{\multicolumn{2}{|c|}{ After peening }} & 48 & 14 & 1 \\
\hline & & & 72 & 14 & 1 \\
\hline & & & 5 & $\mathrm{~N} / \mathrm{D}$ & $\mathrm{N} / \mathrm{D}$ \\
\hline & & & 24 & $\mathrm{~N} / \mathrm{D}$ & $\mathrm{N} / \mathrm{D}$ \\
\hline$"$ & & & 48 & $\mathrm{~N} / \mathrm{D}$ & $\mathrm{N} / \mathrm{D}$ \\
\hline & $0.2-1.6$ & $0.2-1.6$ & 72 & $\mathrm{~N} / \mathrm{D}$ & $\mathrm{N} / \mathrm{D}$ \\
\hline & Ucind & & 5 & 11 & 4 \\
\hline & Using & & 24 & 21 & 15 \\
\hline$"$ & & & 48 & 21 & 15 \\
\hline & $5-10$ & $5-10$ & 72 & 21 & 15 \\
\hline & Using edoe & necks & 5 & 20 & 4 \\
\hline & Using eage & locks & 24 & 27 & 20 \\
\hline " & & & 48 & 27 & 20 \\
\hline & $5-10$ & $5-10$ & 72 & 27 & 20 \\
\hline
\end{tabular}




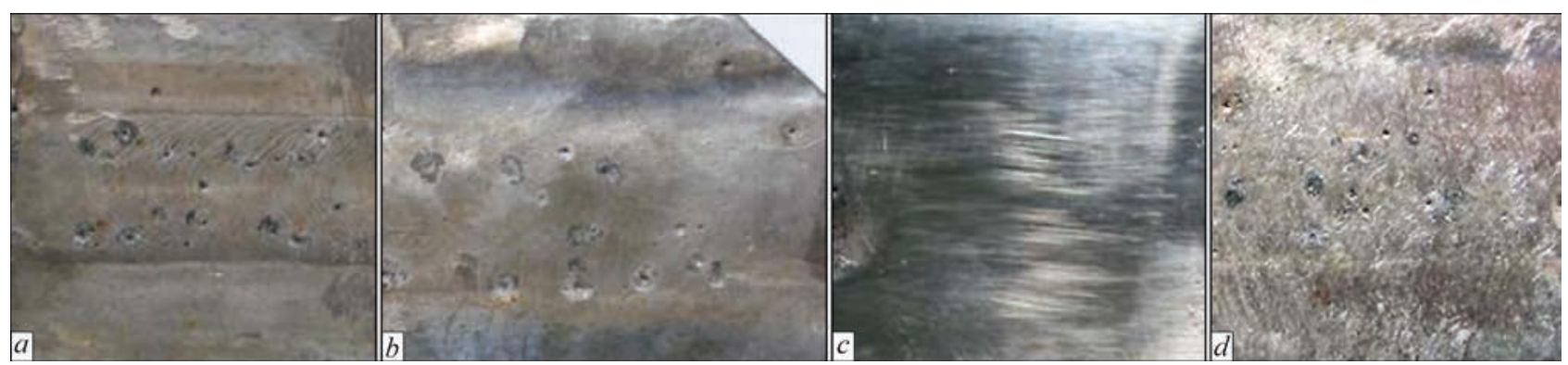

Figure 4. Surface of welded joints of grinded stainless steel tested for pitting corrosion after welding $(a)$, pinning $(b)$, polishing $(c)$ and edge friction $(d)$

presence of surface defects in the sheet rolled metal in combination with unfavorable heating temperatures during welding. The abrasive treatments on grinding machine-tool using disc and those using skin removing the near-surface layers with defects and weld ripples significantly reduce (to single cases) the tendency to pitting formation in welded joints, despite the increase in roughness of the surface (formation of scratches), which remains almost unchanged in the process of corrosion tests (Figure 3, $b$; Table 2).

A significant decrease in number of pits formed in the HAZ metal is achieved by grinding (without visible scratches) of specimen before welding as compared to preservation of their large number in the untreated weld (Figure 4, $a$; Table 2). The tendency to pitting corrosion of the weld is reduced as a result of surface manual and high-frequency mechanical peening (Figure 4, b; Table 2), after which the tensile stresses are reduced and the compressive stresses arise in the metal of subsurface layer [9]. The practical elimination of welded joint tendency to pitting formation is carried out by polishing using vulcanite disc untill getting a mirror shine, combining the removal of the subsurface layer defects with decreasing the surface roughness (Figure 4, $c$; Table 2). The joints treated with mechanical friction, especially with elas- tic shocks, are more prone to pitting formation (Figure 4, $d$; Table 2), the cause of which can be arising of tensile stresses in the subsurface layer. The pits are formed mainly during the first $5 \mathrm{~h}$ of tests, after which their number does not increase significantly.

Preheating of welded specimen of untreated steel and water solution on the electric plate in the process of corrosion tests during $5 \mathrm{~h}$ causes increase in number and sizes of pits formed on the surface of welded joint, especially in the HAZ area at distance of $3-5 \mathrm{~mm}$ from the joint (Figures 3, $a$ and 5, $a$ ). During its test with preheating of solution using the immersed electric heater and forced cooling of the specimen from the reverse side the shallow pits are formed detectable with magnifying glass, mainly on the weld surface (Figures 3, $a$ and 5,b) inferior by number and sizes to the pits formed at room temperature. The reduction in tendency to pitting formation of welded joint occurs due to the combined reduction in its surface temperature and solution in the area of their contact, which is also possible by dispersion of heat through the metal.

Performing the abrasive treatments, particularly polishing, of welded joints and rewelding corrosion-resistant steel and replacing the indirect preheating of aggressive liquid through the wall of tank to direct preheating using the immersed heater from the

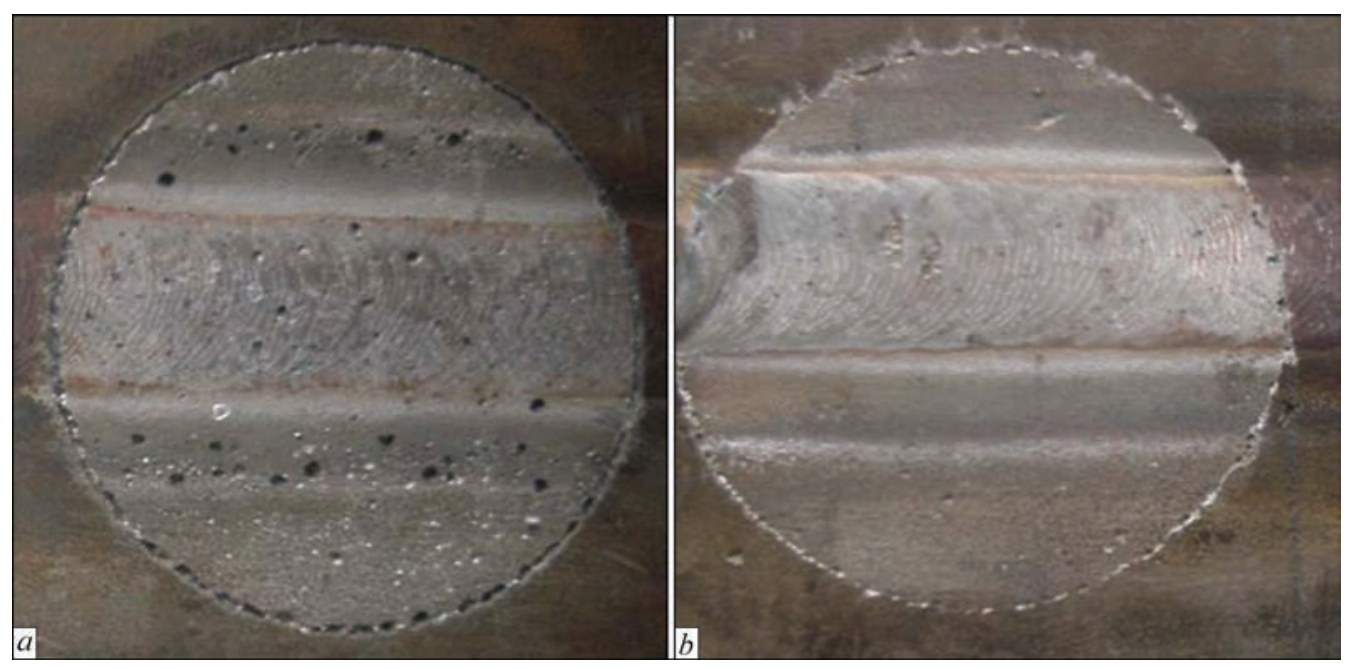

Figure 5. Surface of welded joints of mechanically untreated steel after tests on pitting corrosion with preheating on electric plate $(a)$ and using the immersed electric heater $(b)$ 
inside, helps to increase the reliability and service life of the tank. During outside preheating this is also possible due to dispersion of the supplied heat, when the density of heat flux, the temperature of inner wall and boundary layer of liquid are decreased. It was established that a little increase in pitting resistance of welded joint is achieved by surface peening.

\section{Conclusions}

1. The weld and HAZ of the joints of steel $12 \mathrm{Kh} 18 \mathrm{~N} 10 \mathrm{~T}$ with the same chemical composition of metal, for example, after TIG welding without special treatment are prone to pitting corrosion in formalin.

2. A significant increase in resistance to pitting formation, first of all, in the welded joints of stainless steel is provided by abrasive treatments, especially by polishing, removing the subsurface layers with increased number of defects of different types. At the same time, the roughness (cleanness of treatment) of the surface does not determine the tendency to pitting corrosion. Increasing the resistance against pitting formation is also possible by surface peening, but it is less effective. These treatments are appropriate for application in manufacture and repair of tanks of corrosion-resistant steel.

3. The reliability and service life of tank can be increased by replacing the technological outside preheating through the wall of tank to the preheating of aggressive liquid by the heater immersed from the inside or by dispersion of heat supplied at indirect outside preheating.

1. Nyrkova, L.I., Osadchuk, S.O., Rybakov, A.O. et al. (2015) Monitoring of corrosion state of bimetal tank for products of oil processing and its repair. In: Problems of life and service safety of structures, constructions and machines: Transact., 531-537. Kyiv: PWI.

2. Idelchik, B.M., Lyashchenko, A.E. (1984) Corrosion protection of compressor machines. Leningrad: Mashinostroenie.

3. Tomashev, N.D. (1986) Theory of corrosion and corrosion-resistant structural alloys. Moscow: Metallurgiya.

4. Shabudeeva, L.I., Revyakina, O.K., Makarchuk, T.B. et al. (1996) Effect of heating on corrosion resistance of stainless steel 12Kh18N10T. Fizika Poverkhnosti i Zashchita Materialov, 32(2), 24-30.

5. Yarovchuk, A.V., Voronina, T.A., Tivanova, O.V. (2007) Influence of deformation martensite on resistance to pitting corrosion of stainless steel 12Kh18N10T. Polzunovsky Almanakh, 1/2, 190-196.

6. Pachurin, G.V. (2011) Optimization of modes of surface plastic treatment for increase service life of metal products. Uspekhi Sovr. Estestvoznaniya, 2, 91-95.

7. Knysh, V.V., Valteris, I.I., Kuzmenko, A.Z. et al. (2008) Corrosion fatigue resistance of welded joints strengthened by high-frequency mechanical peening. The Paton Welding J., 4, 2-4.

8. Klimenko, A.V., Solovej, S.A., Kovalenko, S.Yu. (2013) Increase in resistance of pipe steel welded joints to stress-corrosion fracture. Visnyk SkhUkr. NU, 202(13), 178-183.

9. Kyrian, V.I., Knysh, V.V. (2008) High-frequency mechanical peening of welded joints of metal structures. Avtomatich. Svarka, 11, 36-41. 